
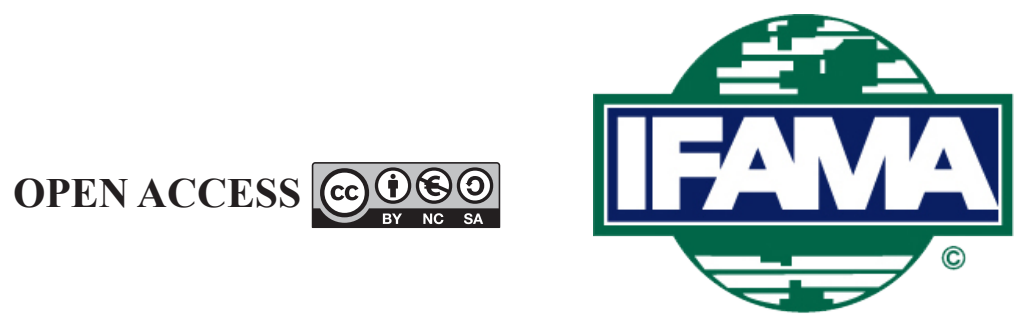

International Food and Agribusiness Management Review

Volume 24, Issue 5, 2021; DOI: 10.22434/IFAMR2020.0064

Received: 28 April 2020 / Accepted: 5 April 2021

\title{
The downfall of Transmar Cocoa
}

\author{
CASE STUDY \\ Ryan Feuz ${ }^{(\mathfrak{a} a}$ and Joseph Montoya ${ }^{\mathrm{b}}$ \\ ${ }^{a}$ Post-Doctoral Researcher, ${ }^{b}$ Graduate student, Department of Applied Economics, \\ Utah State University, 4835 Old Main Hill, Logan, UT 84322, USA
}

\begin{abstract}
As a large cocoa bean trader, Transmar group ltd. bought millions of dollars' worth of beans relying on financing from a syndicate of banks. To monitor amounts of eligible collateral, the banks required Transmar prepare periodic borrowing base (BB) reports. At some point, Transmar developed a discrepancy in collateral recorded on the $\mathrm{BB}$ report versus the amount of funds borrowed. The case discusses how this discrepancy grew larger as many questionable and fraudulent entries were included on subsequent BB reports. The case is written from the perspective of Peter B. Johnson, head of Transmar's European affiliate and son of CEO and founder of Transmar, Peter G. Johnson. In late 2014, Peter B. Johnson first learned about the deceptive practices being employed in preparing the BB reports. How will he react? The case is also rich in details surrounding the cocoa industry supply chain and history of cocoa production.
\end{abstract}

Keywords: ethics, cocoa supply, commodity trading, borrowing base

JEL code: A2, A13, M10

${ }^{\circledR}$ Corresponding author: ryan.feuz@usu.edu

A teaching note has been prepared for this case study. Interested instructors at educational institutions may request the teaching note by contacting the author or IFAMA. 


\section{Introduction}

In late 2014, Peter B. Johnson had a very important decision to make. He was a senior officer of one of the largest cocoa trading companies in the world, Transmar, which owned over \$120 million worth of cocoa beans that were destined to be processed in factories and sold to companies like Hershey, Mars, and Nestle (Harper, 2019). He had just learned some troubling information about some deceptive financial reporting practices within the company and would need to decide how to react.

Transmar was founded and owned by Peter's father, Peter G. Johnson in April of 1980 (Sterk, 2017). From 1980-1990 Peter G. worked hard in his offices in the World Trade Center to build the company and establish Transmar as a recognized name in the industry. Peter G. was a family man and always dreamed of building a company his family would continue to own and operate for generations to come. By 1990, he had three children and wanted to be closer to home to spend time with his wife and children. It was at this time that he moved the company with its small staff of eight to Morristown, New Jersey (Southern District of New York, 2018a). Over the next 30 years, Peter G. worked to expand and build his cocoa trading business. At its height, Transmar was one of the world's 10 largest cocoa processors with more than 350 commercial customers, including Hershey Co., Barry Callebaut, Mars, Nestle, Guittard Chocolate, Ghirardelli Chocolate, and others (Sterk, 2017).

In or about 2002, Transmar expanded into the European market with the formation of Euromar in Germany. Euromar not only bought beans, but also processed them into semi-finished product. Peter B. Johnson spearheaded this expansion and was the active manager of Euromar. Between 2002 and 2013, Transmar continued expanding globally as they pushed to become more vertically integrated within the cocoa industry. Transmar established cocoa butter and liquor-melting operations, built a new processing plant in Ecuador, and increased investments in other cocoa processing operations in New Jersey and other locations both within and outside of the US. All this was done with the ultimate goal of creating a global supply chain for cocoa and cocoa products (United States Bankruptcy Court, 2017). Transmar and its affiliates grew rapidly as Transmar competed for a top spot as one of the largest cocoa traders in the world.

However, Transmar got itself into trouble. Cocoa bean trading is an incredibly capital-intensive industry and requires traders to borrow large sums of money to purchase and move cocoa beans from ports in small countries on the west coast of Africa, halfway across the world to be processed and sold. In order to secure additional capital to support growth and remain solvent during financially stressed times, Transmar employees began manipulating the periodic borrowing base (BB) reports that their lenders required to be submitted. The manipulations were made to overinflate eligible collateral from which they would be allowed to draw upon to receive additional funds from the credit facility they had established with a syndicate of banks. What may have started as a few relatively innocent but perhaps questionable adjustments, quickly spiraled into progressively more fraudulent and illegal misrepresentations to deceive the banks and continue drawing on the credit facility. The deceptive practices got out of hand. The misrepresentations included on the BB reports led to the development of a sizable discrepancy in the amount of eligible collateral Transmar truly possessed and the amount claimed on the BB reports. This discrepancy is referred to as the 'hole' in the BB reports. No one within Transmar appeared comfortable with the deceptive practices but they had worked themselves into a tight spot and could not agree on alternatives. Transmar was reaching a breaking point and running out of options. It was at this time in late 2014 when Peter B. Johnson became aware of the manipulations to inventory on the $\mathrm{BB}$ reports.

Peter B. must now decide how to react to this new discovery. At its core, Transmar was a family company, one that Peter's father had worked tirelessly to build. Peter was well aware of the financial strain the company was now facing. The company and its future legacy undoubtedly weighed heavily on him as he considered his options of how to move forward in light of his grim discovery. 


\section{The cocoa industry}

Cocoa originated in South America in the Andes Mountains of Peru. For a more complete history of cocoa, reference 'The history of cocoa', section of the Appendix. The cocoa industry has evolved massively since it was established in South America over 3,000 years ago, but still looks strikingly similar to what it did then. In the ancient Americas, cocoa was often grown by slaves and enjoyed by the middle and upper classes. In $2018,65 \%$ of the world's cocoa was grown in Africa (Table 1), amounting to 2.9 million metric tons per year. South America still produces a substantial amount of cocoa, but only amounts to $13 \%$ of the world's total production or 605,828 metric tons per year (World Atlas, 2018).

Within Africa, the grand majority of cocoa is grown by impoverished farmers in Ghana and the Ivory Coast on their own private or shared lands. Some, however, is grown illegally on protected land owned by the government. Most African cocoa farmers have never even tasted chocolate. From the farms, the cocoa beans pass through the hands of many players in the supply chain before eventually being bought by co-ops at coastal ports where they are then sold to a handful of large cocoa trading companies. A more complete description of the cocoa bean supply chain is detailed in the Appendix, 'The cocoa supply chain' section. At any given time, there are only about 10 traders operating in the world, and all of the cocoa beans sold in Africa have to go through one of them. Traditionally, these traders have controlled world cocoa prices, regardless of what the farmers and co-ops are making. Of the 10 cocoa traders in the world, three hold the lion's share of business. These three are Cargill, Barry Callebaut, and Olam.

\subsection{Transmar}

Transmar was a relatively new player in the cocoa trading industry. Unlike other major cocoa traders, Transmar initially focused almost exclusively on the trading of cocoa beans. Transmar purchased beans from around the world and sold them to chocolate candy makers like Hershey, Mars, and Nestle. By 2016, Transmar was one of the world's largest cocoa traders, exceeding \$80 million per month in sales (Harper, 2019).

In order to continue growth at such a high rate, Transmar was willing to pay higher prices for their cocoa beans and sell its products for less than companies like Cargill, Olam, or Barry Callebaut. In order to make this business model solvent, the company required a large quantity of throughput. The purchasing of such large quantities of cocoa beans required that Transmar rely on lending institutions to supply financing to the company to purchase the inventory, with the inventory itself used as much of the collateral before being sold. The revenue from sales was then used to pay down the operating loan (Harper, 2019). It was around September of 2011 that Transmar's growth lead them to begin relying on the large syndicate of banks to provide adequate financing. The loan amount available to Transmar at any given time was based on the

Table 1. World cocoa production in 2018 (World Atlas, 2018).

\begin{tabular}{lrr}
\hline Country & Production (metric tons) & World production (\%) \\
\hline Ivory Coast & $1,448,992$ & $32 \%$ \\
Ghana & 835,466 & $18 \%$ \\
Indonesia & 777,500 & $17 \%$ \\
Nigeria & 367,000 & $8 \%$ \\
Cameroon & 275,000 & $6 \%$ \\
Brazil & 256,186 & $6 \%$ \\
Ecuador & 128,446 & $3 \%$ \\
Mexico & 82,000 & $2 \%$ \\
Peru & 71,175 & $2 \%$ \\
Dominican Republic & 68,021 & $2 \%$ \\
Rest of world & 214,152 & $5 \%$ \\
\hline
\end{tabular}


amount of eligible collateral Transmar had in its possession. Eligible collateral could exist in the form of cash, inventory, and receivables, among other assets. To monitor the amount of eligible collateral, the banks required Transmar employees to prepare and submit periodic borrowing base (BB) reports detailing the amount of collateral they had on hand. No matter who prepared the reports, the CEO himself was also required to attest to their accuracy.

Because Transmar operated at the upper levels of its borrowing limits, when the market experienced a surge in demand it was difficult for the company to buy as much as they wanted to capitalize on the upward trend. The cocoa buying and selling industry can typically be characterized as high risk-high return. In order to pay off debts, Transmar assumed massive amount of risk to purchase more beans on credit than their eligible collateral could support. This required the BB reports to be erroneously prepared to reflect greater amounts of eligible collateral on hand, creating the 'hole' in the BB.

\section{The 'hole'}

It is difficult to know exactly how Transmar got into the trouble it was in, or who was to blame. As far as is surmisable, around 2009 or 2010, the former CFO, Dick Krysty failed to write up approximately 10,000 metric tons of real sales of cocoa butter to Euromar which created a false butter long position at Transmar (Southern District of New York, 2018d). This created a situation where ineligible collateral was being stated as eligible on the BB report. This mistake became to be referred to as 'the infamous Dick Krysty non-existent butter position.' After this incident, it appears that as additional BB reports were completed moving forward, the non-existent butter position was not rectified. To make matters worse, Transmar began including other questionable entries on the reports. At some point along the way, a new set of records were created and kept in addition to the accurate or true records. This allowed Transmar to prepare falsified BB reports and continue to draw against the borrowing base to fill the collateral gap.

This practice was maintained to various degrees for up to 7 years, even after Dick Krysty's departure and replacement by Thomas Reich as CFO. Reich recounted a conversation he had as the newly hired CFO with Krysty when the two of them went to lunch during Krysty's last days at Transmar. Thomas claimed that Krysty unfolded all of his tactics used to keep the appearance of the BB in compliance. He detailed how 'circle' transactions were periodically implemented to shuffle eligible collateral around Transmar and its subsidiaries. These transactions were rarely executed other than on paper with their only purpose being to inflate Transmar's eligible collateral values before the submission of a BB reports (Southern District of New York, 2018e). As these tactics continued, the 'hole' became larger and larger, resulting in further justification of false borrowing in hopes of earning enough profits to fix the problem altogether.

\section{The decision}

After discovering the deceptive practices employed in creating the BB reports in late 2014, Peter faced a difficult decision. Transmar had not made a profit for the previous two years. At the time, widespread industry speculation pointed to future increases in cocoa demand due to growth in the Asian markets. As cocoa prices rose in anticipation, Transmar needed more money to invest in more product. The funding had to come from their bank syndicate, which required asking for additional advances. For the funds to be granted, Peter surely knew that the eligible collateral shown on the BB report had to demonstrate the ability to support further draws on the credit facility. With eligible collateral severely lacking, further manipulation of the BB report would be required for the funds to be received. If the speculation of increased demand proved to be accurate, additional profits from Transmar and its affiliates could then be used to fill the hole and rectify the situation.

However, if the speculation proved to be inaccurate and the cocoa market saw no such increase in demand, then the hole would continue to widen and grow ever deeper until the company's deceptive practices would surely be brought to light, and Peter would be implicated in the deception. To avoid this implication Peter would have to report the misrepresentations of the BB to the bank syndicate and possibly other legal authorities. This 
would jeopardize the financial viability of Transmar and most likely, his own company, Euromar, as the two companies were linked in business and had additional shared interests. Beyond financial consequences, this decision would undoubtedly have a lasting effect on Peter's personal relationships with family, employees, and business partners and on his reputation in his community. Transmar had grown to such as size that at this point its demise would cause a tidal wave of pain felt within the entire cocoa industry. Many would have the potential to experience losses, not the least of which would be the cocoa farmers themselves at the beginning of the supply chain. Both Transmar and Euromar had worked to build a good reputation within the industry and had always been good stewards within their communities and within the cocoa production regions from which they purchased. The Johnsons were active members in their respective communities and were looked up to as a family of good character. Peter's father had worked his entire career at building the company, allowing Peter himself to enter the industry and begin his European business adventure. The decision of how to act with the new knowledge of fraud within the company could not be taken lightly.

Peter must now decide how to act knowing whatever decision he makes has the potential to change his life forever. What will it be, Peter?

\section{Follow-up statement}

Instead of doing what I should have done, which was report those problems to the authorities, I provided ideas on mechanisms to fill a hole with assets that I thought were permissible under the credit agreement. That was the pivotal moment that I will regret for the rest of my life.

Peter B. Johnson (Harper, 2019)

Instead of making the banks and authorities aware of the problem with previous BB reports, Peter began actively participating in the manipulation of the reports. This is not to say that he did not take issue with the problem and find it alarming. Emails collected by the courts revealed many attempts to rectify the problem by eliminating false inventory. This is evident in an email written by Peter to the other chief officers of Transmar in which he stated:

Eliminate ALL of the fake inventory. Take more receivables from Euromar, even if they aren't technically borrowable. Circle inventory through intermediaries if necessary. Take all the loans that Euromar has granted to various related entities onto Transmar balance sheet. But I repeat, there should be ZERO ZERO ZERO fake inventory in our end of month borrowing base and this must remain so going forward. (Southern District of New York, 2018c: 2)

Their efforts however, were in vain, as the hole quickly grew to greater proportions and Transmar continued to rely on falsified reporting to keep the BB in compliance with the amount of funds borrowed.

The 'fraud scheme', as it came to be known in the court records, snowballed into a massive hole. It became an open secret among the Johnson family and several other chief officers and employees in the company in charge of maintaining the financial books and preparing the BB reports. They talked about the hole and how it should be addressed frequently in email conversations documented by the courts. They often discussed among each other the best methods to 'fill the hole' and not raise alarm as each new BB report became due. According to court documents, the BB reports were falsified through such methods as: '(a) including collateral on the BB's that Transmar no longer owned or that was stored under conditions that made it ineligible for inclusion in the BB's; (b) including receivables on the BB's for which Transmar had already been paid or were too old to be eligible for inclusion in the BB's; and (c) engaging in 'circle' transactions, that is, transactions that involved the nominal sale of assets to amenable third-parties, in order to create the appearance of actual business and generate receivables that, on their face, could be included in the BB's' (Southern District of New York, 2018b: 3). Thus, what started innocently enough quickly became a complete case of fraud. 


\section{The rest of the story}

In 2014, speculation that Asian markets would begin to purchase more cocoa caused the price of cocoa beans to surge from $\$ 2,200$ per metric ton to $\$ 3,435$ per metric ton in December 2015. In order to make money on this forecasted increase in demand, reflected by the increase in price, Transmar needed to borrow more money. To be able to do so, under the direction of Peter G. Johnson, chief financial officer Thomas Reich submitted proposals to the bank to increase credit to around $\$ 400$ million. The bank needed collateral, and Reich cited hundreds of thousands of dollars of fake inventory of cocoa beans in order to persuade them. With aid from both Peter B. and Peter G. Johnson the fraud scheme continued with the BB reports repeatedly falsified (Harper, 2019).

In 2016, William Yu who had begun taking over the duties of CFO and Nancy Pizzi, a senior staff accountant, who was in charge of keeping track of Transmar's two sets of books, expressed worries to the Johnson's and to Thomas Reich about the growing hole. Peter B. and Peter G. met together to solidify a plan to further cover up the fraud by continuing the practices of circle transactions and reverse invoices. They assured $\mathrm{Yu}$ and Pizzi that all would be well. This plan ushered in a time for Transmar that became increasingly turbulent. Nathanial Durant, who was an overseas officer of Transmar, was transferred to Transmar's main offices to help with financial duties. He independently discovered the fraud and ardently disagreed with the Johnson's decision to deepen it. Yu and Pizzi, who had been feeling the pressure from the decisions Peter B. in particular had been making, quickly moved to support Durant. Durant wrote an email to Peter G. requesting that Peter B. be fired and that a partial disclosure of the fraud be made to the banks. Peter G. seriously considered Durant's plan including firing Peter B., but decided against it. He did agree with Durant's decision of making a partial disclosure to the banks and moved forward to do so.

Peter B. considered this 'suicide' and after finding out, resigned from his role in the company. To make matters worse, the expected surge in cocoa demand in Asia never happened. In the first quarter of 2016, cocoa prices fell to $\$ 1,917$ per metric ton (Figure 1), less than it had been before the speculation. Transmar was millions of dollars in debt and was sure to lose even more money on its physical purchase in the down market. As the market stagnated, combined with the effects of the Brexit vote in the United Kingdom, the collateral position of Transmar became further jeopardized. On December 31, 2016 after not being able to pay back the banks, Transmar filed for chapter 11 bankruptcy protection. During the bankruptcy proceedings, it became very clear that Transmar was operating outside of the law.

The State of New York pressed charges criminally. Ultimately, Peter B. Johnson received a prison sentence of 30 months for his involvement in the fraud while his father and Thomas Reich received 36 months and 3 months respectively (Southern District of New York, 2018f,g,h). No other employees within Transmar received any prison sentence. The fallout to the banks was astounding, with a combined loss estimated at \$325.5 million. On August 7, 2017, the lenders sued Peter G. Johnson, Peter B. Johnson, Mary Johnson (Peter G.'s wife), Timothy Johnson (Peter B.'s brother), Thomas Reich, Richard Gary O'Connor, Nancy Pizzi, and William Yu. They were taken to court over the $\$ 325.5$ million dollars of unrecoverable loans. Efforts to recover losses were largely unsuccessful. Table 2 displays the amount of outstanding loan balances to members of the bank syndicate at the time of the court case.

Cocoa farmers suffered as well because of the speculation and consequent drop in price. Because of the speculation, farmers in West Africa produced 500,000 metric tons more cocoa than in the previous year, much of which was undoubtedly grown illegally on protected national park lands. It is speculated that other traders bought this cocoa at a fraction of the normal cost. Consumers did not see a drop in the price of chocolate, suggesting that traders and candy companies enjoyed higher margins due to the price drop (Harper, 2019). 


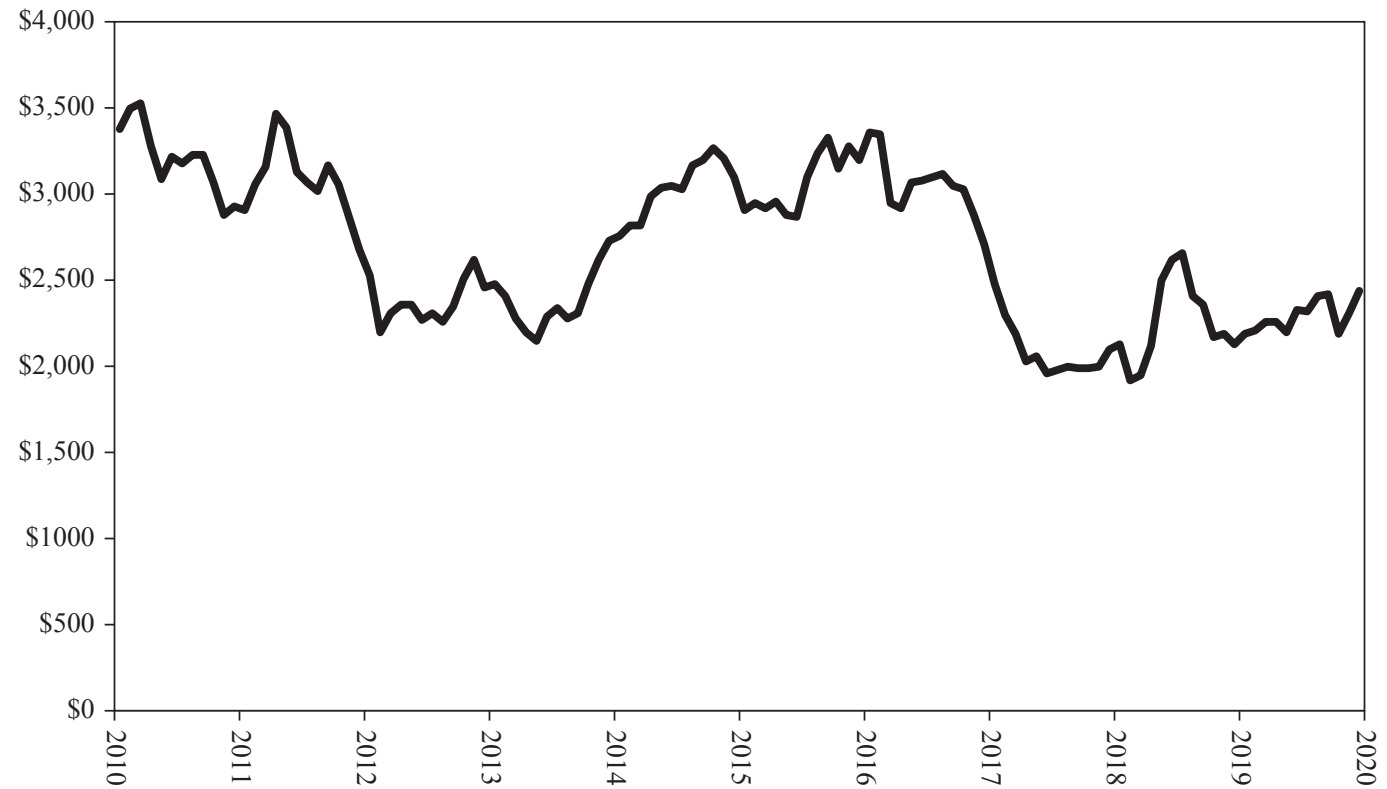

Figure 1. Cocoa bean prices per metric ton (2010-2019) (IndexMundi, 2020).

Table 2. Transmar outstanding loan balance for members of bank syndicate (United States District Court District of New Jersey, 2019).

\begin{tabular}{lll}
\hline Lender & $\mathbf{2 0 1 6}$ & Amount outstanding \\
\hline ABN AMRO Capital USA & $\$ 76,478,750$ & $\$ 74,906,250$ \\
Societe Generale & $\$ 62,982,500$ & $\$ 61,687,500$ \\
BNP Paribas & $\$ 53,985,000$ & $\$ 52,875,000$ \\
Natixis, New York Branch & $\$ 53,985,000$ & $\$ 52,875,000$ \\
Macquarie Bank & $\$ 40,488,750$ & $\$ 39,656,250$ \\
Bank Hapoalim & $\$ 31,491,250$ & $\$ 30,843,750$ \\
MUFG Bank & $\$ 26,992,500$ & $\$ 26,437,500$ \\
Israel Discount Bank of New York & $\$ 13,496,250$ & $\$ 13,218,750$ \\
Total & $\$ 359,900,000$ & $\$ 352,500,000$ \\
\hline
\end{tabular}

${ }^{1}$ Amount outstanding after various collection efforts as of $8 / 06 / 18$.

\subsection{Lessons learned}

The fallout of the fraud was devastating to all involved. The close-knit family company that Peter G. had worked so hard to build for all those years was completely decimated. The financial institutions involved in the bank syndicate lost hundreds of millions of dollars. Perhaps most devastating to the Johnson's was the tremendous strain placed on relationships with family and friends.

The fallout was not isolated to Transmar and the Johnson family. As one of the top 10 largest cocoa processors/ traders, with over 350 commercial customers, including names such as Hershey, Mars, and Nestlé, the collapse of Transmar was felt throughout the entire cocoa industry from bean to chocolate bar. Without the expected increase from demand in Asia, cocoa prices were already suffering in 2016. Transmar filing for bankruptcy only further added to the shakiness of the market and downward pressure of prices (Terazono, 2017a). The downfall of Euromar as a large processor of cocoa beans into cocoa butter also contributed significantly to a severe shortage of cocoa butter in 2016 (Terazono, 2017b). This undoubtedly had negative short-term effects on the many companies that produce products from cocoa butter. In the long run, the exit of Transmar 
may have allowed for some smaller firms within the cocoa industry to experience some growth, especially within their physical trading departments. These firms capitalized on the demise of Transmar by filling the gap in cocoa trading brought about with the loss of Transmar's throughput (Ionova, 2018).

Financing of these capital-intensive commodity trading/processing industries such as cocoa and coffee can be a risky business. Many of the large financial institutions that finance cocoa are also the same players involved in financing of other similar commodities. With total bank losses estimated at $\$ 352.5$ million, the downfall of Transmar had a devastating effect on the financial security of these banks. Not only did the banks (and those employed by the banks) suffer, but also the industries they help finance. While these types of ripplingeffect-losses are difficult to quantify, they were certainly felt throughout the cocoa industry as well as other inter-connected industries. Those within the cocoa industry feared that financing would become scarcer. They also feared that to acquire the limited financing still available, they would be required to undergo increased scrutiny as well as submit to more costly safeguards put in place by the lenders (Terazono, 2017b). Again, while concrete estimates of costs imposed by the downfall of Transmar may be difficult to estimate, they are no less real and significant to those who remained in the industry.

The Johnsons were strong members of their communities and were well known and respected for their commitment not only among their business relationships, but more importantly to them, their friends and family. The letters of support that poured in and were submitted to the judge of the criminal case against them, depicted both Peter B. and G. as men of great character who took pride in being active in their communities and were respected within their communities. The Johnsons undoubtedly faced significant pressure to uphold their reputations. One thing became abundantly clear throughout the proceedings of the court case; the Johnsons are good people but in the end, sometimes, good people make very bad mistakes.

The Transmar fraud case was not a typically white-collar crime. While certainly the Johnsons made a good living, it does not appear that the fraud was set in place as a way to enrich themselves personally. Instead, the fraud appeared to be slowly set in motion, always with the intent that the 'hole' could and would be eventually rectified as markets stabilized and business progressed. Those involved in the fraud did not appear to plan out an elaborate 'get rich' scheme, but rather made difficult decisions as they were faced with them, which although were ethically questionable, they felt were justified to preserve the company and way of life of their employees and business partners. The preservation of their own reputations within their industry and communities would have also certainly played a role in the decisions they made. This case demonstrates how often unethical decisions within business are made on the margin, one choice at a time.

\section{Supplementary material}

Supplementary material can be found online at https://doi.org/10.22434/IFAMR2020.0064

\section{Appendix.}

\section{References}

Harper, A. 2019. Rotten: bitter chocolate. Zero Point Zero Production, New York, NY, USA. IndexMundi. 2020. Cocoa monthly price - US dollars per kilogram. April 24, 2020. Available at: https:// www.indexmundi.com/commodities/?commodity=cocoa-beans\&months $=120$

Ionova, A. 2018. After big-name cocoa sector exits, small firms start filling trade gap. Yahoo! Finance, 10 August 2018. Available at: https://sg.finance.yahoo.com/news/big-name-cocoa-sector-exits-smallfirms-start-162307954--finance.html

Southern District of New York. 2018a. Document 83-1: United States v. Peter G. Johnson. 1:17-cr-00482JSR. July 30. Southern District of New York, New York, NY, USA.

Southern District of New York. 2018b. Document 84: government's sentencing memorandum. 1:17-cr00482-JSR. August 6. Southern District of New York, New York, NY, USA. 
Southern District of New York. 2018c. Document 90-85: Exhibit 85. 1:17-cr-00482-JSR. September 10. Southern District of New York, New York, NY, USA.

Southern District of New York. 2018d. Document 92-5: Exhibit E. 1:17-cr-00482-JSR. September 14. Southern District of New York, New York, NY, USA.

Southern District of New York. 2018e. Document 94. 1:17-cr-00482-JSR. September 14. Southern District of New York, New York, NY, USA.

Southern District of New York. 2018f. Judgment in a Criminal Case for Peter B. Johnson. 1:17-cr-00482JSR: Document 98. September 28. Southern District of New York, New York, NY, USA.

Southern District of New York. 2018g. Judgment in a Criminal Case for Peter G. Johnson. 1:17-cr-00482JSR: Document 86. August 20. Southern District of New York, New York, NY, USA.

Southern District of New York. 2018h. Judgment in a Criminal Case for Thomas Reich. 1:17-cr-00482-JSR: Document 99. October 2. Southern District of New York, New York, NY, USA.

Sterk, R. 2017. U.S. cocoa processor Transmar files Chapter 11. Food Business News, 9 January 2017. Available at: https://www.foodbusinessnews.net/articles/8729-u-s-cocoa-processor-transmar-fileschapter-11

Terazono, E. 2017a. Transmar woes add to cocoa market jitters. Financial Times, 6 January 2017. Available at: https://www.ft.com/content/4523752e-d39c-11e6-9341-7393bb2e1b51

Terazono, E. 2017b. Cocoa group's bankruptcy fuels bank lending concerns. Financial Times, 2 February 2017. Available at: https://www.ft.com/content/f5098c08-e8a0-11e6-967b-c88452263daf

United States Bankruptcy Court. 2017. Declaration of Robert J Frezza in support of Debtor's chapter 11 petition and first day motions. 16-13625 (JLG): Document 4, January 3. United States Bankruptcy Court, Southern District of New York, New York, NY, USA.

United States District Court District of New Jersey. 2019. Document 109-1. 2:18-cv-00246-SDW-CLW. February 28. United States District Court District of New Jersey, Camden, NJ, USA.

World Atlas. 2018. Top 10 cocoa producing countries. Reunion Technology Inc., St. Laurent, QC, Canada. Available at: https://www.worldatlas.com/articles/top-10-cocoa-producing-countries.html 
